\begin{tabular}{c}
\hline TÜRK \\
TARIM ve DOĞA BILIMLERI \\
DERGISI \\
\hline \hline
\end{tabular}

\section{Research Article}

www.dergipark.gov.tr/turkjans

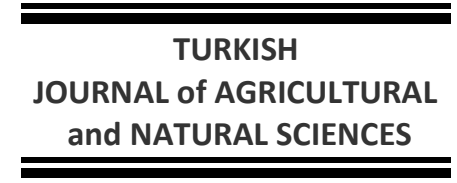

\title{
A Preliminary Study on Determination of Small Carrion Visitor Sarcophagidae (Diptera) Species from Yozgat (Turkey), with Two New Records
}

\author{
Gamze PEKBEY*
}

Department of Plant Protection, Faculty of Agriculture, Yozgat Bozok University, Yozgat, Turkey

*Corresponding author: gamze.pekbey@bozok.edu.tr

Received: 22.02.2019

Received in Revised: 23.05.2019

Accepted: 21.06 .2019

\begin{abstract}
This study was conducted during the April and October 2017 to determine the small carrion visitor flesh fly (Diptera: Sarcophagidae) species in Yozgat province of Turkey. The experiments were carried out simultaneously in the funnel type traps which were hung in three different directions of six selected poplar trees in Bozok University, Erdogan Akdag Campus. For this purpose, chicken livers were used as bait to attract the adult flies. The specimens were collected daily and a total of 21 flesh fly species were identified. While Sarcophaga (Liopygia) argyrostoma (Robineau-Desvoidy, 1830), Sarcophaga (Bercaea) africa (Wiedemann, 1819) and Ravinia pernix (Harris, 1780) were found the most common and abundant, S. (Liosarcophaga) tuberosa Pandellé, 1896 and S. (Helicophagella) novercoides Bottcher, 1913 were rarely encountered species in the traps. All species were recorded for the first time in Yozgat and additionally, S. (Liosarcophaga) aegyptica Salem, 1935 and S. (Golania) platariae Povolný, 1992, representing new records for Turkish fauna. Climatic data and seasonal species distributions of the study area were also provided.
\end{abstract}

Key words: Bait traps, decomposition, flesh flies, fauna, identification.

\section{İki Yeni Kayıtla Birlikte, Yozgat ili Küçük Leş Ziyaretçisi Sarcophagidae (Diptera) Türlerinin Belirlenmesi Üzerine Bir Ön Çalışma}

\section{Özet}

Bu çalışma, 2017 yılı Nisan ve Ekim ayları arasında Yozgat ili küçük leş ziyaretçisi et sineği (Diptera: Sarcophagidae) türlerinin belirlenmesi amacıyla yapılmıştır. Denemeler Bozok Üniversitesi, Erdoğan Akdağ Kampüsünde seçilen altı kavak ağacına aynı anda üç farklı yöne asılan funnel tipi tuzaklarda gerçekleştirilmiştir. Ergin et sineklerini çekmek amacıyla her bir tuzakta yem olarak tavuk ciğeri kullanılmıştır. Örnekler günlük olarak toplanmış ve toplam 21 et sineği türü teşhis edilmiştir. Sarcophaga (Liopygia) argyrostoma (RobineauDesvoidy, 1830), Sarcophaga (Bercaea) africa (Wiedemann, 1819) ve Ravinia pernix (Harris, 1780) türleri en yaygın ve sık türler olarak bulunurken, S. (Liosarcophaga) tuberosa Pandellé, 1896 ve S. (Helicophagella) novercoides Bottcher, 1913 ise tuzaklarda en az rastlanan türler olmuştur. Türlerin tamamı Yozgat ilinde ilk kez kaydedilmiş ve ayrıca S. (Liosarcophaga) aegyptica Salem, 1935 ve S. (Golania) platariae Povolný, 1992 ise Türkiye faunası için yeni kayıtları temsil etmiştir. Çalışma alanın iklim verileri ve mevsimsel tür dağılımları da sağlanmıştır.

Anahtar kelimeler: Dekompozisyon, et sinekleri, fauna, teşhis, yem tuzağı.

\section{Introduction}

Two dipteran families Calliphoridae (blow flies) and Sarcophagidae (flesh flies) are known as the first visitors of the carrions (Campobasso et al., 2001; Amat, 2010). Their high mobility and improved sense organs provide them to find and colonize rapidly on decaying tissues within minutes (Vairo et al., 2017). Therefore, these two family are the most utilized insect species in forensic entomology experiments (Campobasso et al., 
2001; Cherix et al., 2012; Kyerematen et al., 2013; Ren et al., 2018).

The adult sarcophagids mainly feed on various fluids or sugar containing materials such as nectar, but larvae have a large scale of feeding habits such as coprophagy, necrophagy, saprophagy, predation or parasitism in invertebrates (such terrestrial arthropods, annelids or molluscs) and myiasis producing in vertebrates (Pape, 1987; Pe'rez-Moreno 2006; Farkas et al.,
2009; Cherix et al., 2012). To predict the limits of these habits for all species are not easy because of the so many facultative tendencies, particularly for the most diverse genus Sarcophaga. These biological transitions could be more confused and misleading for the researchers when combined with the local biodiversity and identification problems of both sexes and larval stages (Amendt et al., 2011; Szpila et al, 2015; Ren et al., 2018).

Table 1. The list of necrophagous, forensically important and myiasis agent flesh fly species reported from Turkey

\begin{tabular}{|c|c|c|}
\hline Species & References & Determined material \\
\hline Wohlfahrtia magnifica & $\begin{array}{l}\text { (Şaki and Özer, 1999a; Şaki and Özer, } \\
\text { 1999b; Özdal, 2004; Sevgili et al., 2004; } \\
\text { Ütük, 2006; Açıkgöz, 2008; Aydenizöz } \\
\text { and Dik, 2008; Akduman et al., 2011; } \\
\text { Dik et al., 2012; Tereli et al., 2015; } \\
\text { Beyhan et al., 2017) }\end{array}$ & $\begin{array}{l}\text { Myiasis in living cows, sheep, } \\
\text { goats, decaying meat, liver and } \\
\text { spleen pieces, myiasis in dog, } \\
\text { gingival myiasis in lamb, } \\
\text { otomyiasis in human, rabbit } \\
\text { carcass, human corpse }\end{array}$ \\
\hline $\begin{array}{l}\text { S. (Bercaea) africa } \\
\text { as S. haemorrhoidalis or } \\
\text { as S. africa }\end{array}$ & $\begin{array}{l}\text { (Şaki and Özer, 1999b; Sevgili et al., } \\
\text { 2004; Açıkgöz, 2008; Özcan, 2008; } \\
\text { Yuca, 2009; İpek et al., 2011; Dik et al., } \\
\text { 2012; Çoban and Beyarslan, 2013) }\end{array}$ & $\begin{array}{l}\text { Decaying meat, liver and spleen } \\
\text { pieces, dog carcass, pig carcass, } \\
\text { human corpse }\end{array}$ \\
\hline S. (S.) carnaria & $\begin{array}{l}\text { (Şaki and Özer, 1999b; Karapazarlıŏlu, } \\
\text { 2004; Özdal, 2004; Sevgili et al., 2004; } \\
\text { Karapazarlıoğlu, 2010; Tereli et al., } \\
\text { 2015; Ergün et al., 2016; Ekmekçi, } \\
\text { 2017) }\end{array}$ & $\begin{array}{l}\text { Decaying meat, liver and spleen } \\
\text { pieces, pig carcass, rabbit carcass, } \\
\text { myiasis in human }\end{array}$ \\
\hline S. (Liopygia) argyrostoma & $\begin{array}{l}\text { (Karapazarlıoğlu, 2004; Özdal, 2004; } \\
\text { Sevgili et al., 2004; Karapazarlıoğlu, } \\
\text { 2010; Tereli et al., 2015; Ekmekçi, } \\
\text { 2017; Kökdener et al., 2018) }\end{array}$ & $\begin{array}{l}\text { Decaying meat, liver and spleen } \\
\text { pieces, pig carcass, rabbit carcass, } \\
\text { dog carcass, chicken liver }\end{array}$ \\
\hline S. (Liopygia) crassipalpis & (Tereli et al., 2015) & Rabbit carcass \\
\hline $\begin{array}{l}\text { S. (Liosarcophaga) dux } \\
\text { [as S. exuberans] }\end{array}$ & (Açıkgöz, 2008) & Human corpse \\
\hline S. (Pandelleisca) similis & Kökdener et al., 2018 & Chicken liver \\
\hline Sarcophaga sp. or spp. & $\begin{array}{l}\text { (Yazar et al., 2005; Türk et al., 2006; } \\
\text { Dağcl et al., 2008; Öktener and Alas, } \\
\text { 2009; Sert et al., 2012; Kaya et al., } \\
\text { 2014; Polat et al., 2016) }\end{array}$ & $\begin{array}{l}\text { Myiasis in human, myiasis in fish, } \\
\text { dog carcass }\end{array}$ \\
\hline
\end{tabular}

The carrion relevant sarcophagids could be separated into two general groups to their assemblage priority, as necrophagous and carrion visitors. The first one characterized by the larval activity which means the female use the carrions as an ovipositing (or larvipositing for the flesh flies) site and the larvae consume it obligatory. Therefore, they have the major importance in forensic investigations with minor species diversity (Amendt et al., 2011; Rivers and Dahlem, 2014; Szpila et al., 2015). Even though, many flesh fly larvae could be successfully fed on the small carrions in vitro, this may not be always the sign of natural necrophagous behaviour due to the primary breeding preferences (Rivers and Dahlem, 2014). For instance, $S$. africa is one of the most cosmopolitan and common species of the forensic investigations, but as being a coprobiodotic species, it prefers to deposit their larvae to faeces rather than the corpse (Cherix et al., 2012; Ren et al, 2018). The latter group consists of the adults that only visit the carrions for copulation or having protein rich meals after the emerging from puparium or egg production without oviposition. (Cherix et al., 2012; Martín-Vega and Baz, 2013; Rivers and Dahlem, 2014, 2014; Szpila et al., 2015). Various ecologies constitute new biogeoclimatic zones; hence, diversity and 
abundance of the flesh flies vary from region to region relatively (Pape 1987; Blackith and Blackith 1990). In this sense, Turkey has a very special location of being at the confluence of the Caucasus, Irano-Anatolian, and Mediterranean biodiversity spots (Şekercioğlu et al, 2011). Eventually with the recent faunistic and taxonomic studies, the number of the flesh fly species known from Turkey increased to 152 (Verves et al., 2018; Whitmore et al., 2018). Of which only 6 species (except unknown Sarcophaga spp.) of sarcophagids have been reported from Turkey as myiasis agent, necrophagous or having forensic importance, by now. (Table 1). Among them, Wohlfahrtia magnifica (Schiner, 1862) is known as the third most important obligatory myiasis producing species in the world and the first in Turkey (Şaki and Özer, 1999a, 1999b; Ren et al., 2018).

In Europe, 33 species of flesh flies have been listed from the large carcasses (Szpila et al., 2015). Clearly, total number of the carrion relevant species of Sarcophagidae listed in Turkey is fairly low as compared to European records.

This study focuses to provide preliminary data to species compositions and succession of the small carrion visitor flesh flies and to exemplify species diversity of Turkey in the scale of Yozgat.

\section{Material and Methods Study area}

The study was conducted between the April and October of 2017, in Yozgat Bozok University Erdogan Akdag Campus. This site lies between the coordinates $39^{\circ} 46^{\prime} 22^{\prime \prime} \mathrm{N}, 34^{\circ} 48^{\prime} 11^{\prime \prime} \mathrm{E}, 1339 \mathrm{~m}$ in height and covers 410 ha. It is located southwest of Yozgat province and about $13 \mathrm{~km}$ distant from the city centre. As the result of the typical continental climate conditions, general vegetation is characterized by steppes and arid zones. Additionally, some natural (mainly composed of Robinia pseudoacacia, Eleagnus angustifolia, Populus alba, P. tremula and Cedrus libani) and artificial ornamental trees (Tilia argentea, Cedrus libani. Picea pungens glauca, Cotoneaster sp., Berberis thunbergii and Rosa spp.) are found (Irgatoğlu, 2011). The experiments were performed on the Populus spp. for standardization of the samplings.


Figure 1. Traps and collection of flesh flies. A. Preparation of baits. B. Traps C-D. Hanging the traps and collecting the adult flies $\mathrm{E}$. Collected flies.

\section{Collection of the adults}

The experiments were carried out with a total quantity of 18 commercially designed funnel type fly traps $\left(\operatorname{SinTuz}{ }^{\circledR}\right)$ of which analogues were formerly used by some authors (Aak et. al., 2010; Tschorsnig et al., 2011; Khoobdel et al., 2013). 75 gr of chicken liver pieces were used as attractant. The trap liquid was prepared with water and 
odourless soap in order to reduce surface tension (Fremdt and Amendt., 2014). The baits were put into the net tulle covered transparent plastic cups and then placed into the traps (Figure 1A, B). Three traps were hung in different directions of six selected Populus spp. trees to increase the chance of captures (Figure 1C, D). The specimens were collected by daily and the baits were renewed in each 7 days (25 times in 175 days). All obtained insects were separated to their taxa and selected flesh flies were put into the petri dishes by recording the dates and stored at $-20 \circ \mathrm{C}$ until the identification stage (Figure $1 \mathrm{E}$ ).

The daily temperature and relative humidity values of the locality were measured by LYK-20E ${ }^{\circledR}$ data logger throughout the study (Figure 2).

\section{Species identification}

The genitalia of the specimens were dissected under Leica ${ }^{\circledR}$ S8APO stereomicroscope. Some of them were softened in $10 \% \mathrm{KOH}$ for further diagnosis. After the pinning and labelling procedure, all examined materials were kept in the entomology laboratory.

The specimens were identified by using Richet et al. (2011) and Povolný (1992). For classification Pape (1996) was followed.

\section{Results and Discussion}

21 species from a total of 457 specimens were identified (Table 2).

Except Sarcophila meridionalis Verves, 1982 (Paramacronychiinae) and Taxigramma heteroneura (Meigen, 1830) (Miltogramminae), the other 19 species were determined as belonging to

Table 2. Seasonal distributions and percentages of the species

\begin{tabular}{|c|c|c|c|c|c|c|c|}
\hline \multirow{2}{*}{ Species } & \multicolumn{7}{|c|}{ Number of individuals } \\
\hline & April & May & June & July & August & September & October \\
\hline Blaesoxipha (B.) batilligera Ség., 1941 & 0 & 0 & 0 & 0 & 0 & 1 & 0 \\
\hline Ravinia pernix (Harris 1780) & 4 & 7 & 6 & 13 & 11 & 6 & 4 \\
\hline Sarcophila meridionalis Verves 1982 & 5 & 7 & 9 & 14 & 5 & 4 & 2 \\
\hline S. (Bercaea) africa (Wiedemann 1819) & 6 & 5 & 8 & 12 & 11 & 6 & 5 \\
\hline *S. (Golania) platariae Povolný 1992 & 0 & 0 & 0 & 2 & 5 & 11 & 0 \\
\hline S. (Helicop.) hirticrus Pandellé 1896 & 0 & 0 & 0 & 3 & 4 & 2 & 0 \\
\hline S. (Helicop.) melanura Meigen 1826 & 1 & 3 & 4 & 6 & 4 & 4 & 1 \\
\hline S. (Helicop.) novercoides Bottcher 1913 & 0 & 0 & 0 & 1 & 3 & 0 & 0 \\
\hline S. (Het.) helenae (Trofimov 1948) & 0 & 0 & 0 & 5 & 4 & 2 & 0 \\
\hline S. (Liop.) argyrostoma (Rob.-Desv. 1830) & 2 & 8 & 10 & 16 & 11 & 2 & 5 \\
\hline S. (Liop.) crassipalpis Macquart, 1839 & 5 & 2 & 9 & 12 & 7 & 5 & 3 \\
\hline *S. (Liosar.) aegyptica Salem 1935 & 0 & 1 & 2 & 4 & 3 & 1 & 0 \\
\hline S. (Liosar.) emdeni (Rohdendorf 1969) & 0 & 0 & 3 & 2 & 1 & 0 & 0 \\
\hline S. (Liosar.) jacobsoni (Rohd. 1937) & 0 & 0 & 3 & 2 & 1 & 2 & 0 \\
\hline S. (Liosar.) portschinskyi (Rohd. 1937) & 0 & 0 & 1 & 2 & 2 & 0 & 0 \\
\hline S. (Liosar.) tuberosa Pandellé 1896 & 0 & 0 & 0 & 0 & 3 & 1 & 0 \\
\hline S. (Myorhina) nigriventris Meigen 1826 & 0 & 0 & 3 & 2 & 2 & 1 & 1 \\
\hline S. (Sarcophaga) bergi Rohdendorf 1937 & 3 & 4 & 13 & 14 & 5 & 3 & 0 \\
\hline S. (Sarcophaga) lehmanni Mueller 1922 & 3 & 6 & 11 & 13 & 8 & 7 & 2 \\
\hline Taxigramma heteroneura (Meig., 1830) & 0 & 0 & 0 & 0 & 1 & 0 & 0 \\
\hline S. (Thyrsoc.) incisilobata Pandellé 1896 & 0 & 0 & 3 & 4 & 1 & 0 & 0 \\
\hline TOTAL (n) & 29 & 43 & 85 & 127 & 92 & 58 & 23 \\
\hline PERCENTAGE (\%) & 6.35 & 9.41 & 18.6 & 27.79 & 20.13 & 12.69 & 5.03 \\
\hline
\end{tabular}

*New records of Turkey

The highest number of individuals were determined as S. (Liopygia) argyrostoma (12.05\%), S. (Bercaea) africa (11.83\%), R. pernix (11.38\%) and S. (Sarcophaga) lehmanni (11.16\%). Conversely, S. (Helicophagella) novercoides (0.89\%), S. (Liosarcophaga) tuberosa (0.89\%) and $S$. (Liosarcophaga) portschinskyi (1.12\%) were obtained at the lowest rates. On the other hand, only just a single male of Blaesoxipha (Blaesoxipha) batilligera Séguy, 1941 and Taxigramma heteroneura (Meigen, 1830) were collected. From these, $T$. heteroneura is mainly known as kleptoparasites of sphecids or parasitoids of some grasshoppers (Pape, 1987) and, Blaesoxipha spp. is widely known as the parasitoids of the acridids, only B. (Gigantotheca) plinthopyga Wiedemann, 1830 was reported as necrophagous (Denno and Cothran 1976). Eventually, the occurrence of these two single individuals in the traps seems coincidentally. 
Likewise, Szpila et al., (2015) mentions the accidental existing of two single Miltogramminae species on pig carcass. Additionally, the presence of S. (Liosarcophaga) aegyptica Salem, 1935 and S. (Golania) platariae Povolný, 1992 were elicited for the first time in Turkey. The highest numbers of species were collected in the summer months as expected. Because of the August of 2017 was rainier and the average temperature was lower than the previous month in Yozgat (Figure 2), the most number of the specimens visited the traps in July (Table 2).

According to the decaying stages, the highest number of individuals were collected in active decaying stage (between the $2-3^{\text {th }}$ days) and the lowest were at the dry stage $\left(6-7^{\text {th }}\right.$ days). $R$. pernix, S. (B.) africa, S. (Helicop.) melanura, $S$. (Liopy.) argyrostoma, S. (Liopy.) crassipalpis, Sarcophila meridionalis, S. (S.) lehmanni and S. (S.) bergi were found in all decaying stages in proportion to their predominance. The other species were only involved especially in relatively hot days and generally in active decaying stages
(Figure 3). At the fresh stages, mostly Calliphoridae $(53.2 \%)$ adults were obtained in the traps. But the higher abundance and visit frequency of adults does not be indicator of the earlier colonization. In that case, larval development is more important (Szpila et al. 2015). Visits of the individuals and species diversity of Sarcophagidae increased towards to the active stages of the decomposition but significantly decreased at the further decaying stages (Figure 3-4).

The higher numbers of females were recorded in the species of $S$. africa $(+13 \%), S$. lehmanni (+10\%), S. argyrostoma (+8\%), S. crassipalpis (+5\%), S. melanura (+5\%), S. aegyptica $(+1 \%), S$. emdeni $(+2 \%)$ and $S$. bergi $(+2 \%)$. Male ratios were found higher than the females for remain. Additionally, T. heteroneura, B. batilligera and $S$. platariae were represented by only males. Both sexes predominantly visited the traps in active decaying stages, but the males were found higher in advanced stage than the females (Figure 3-4).

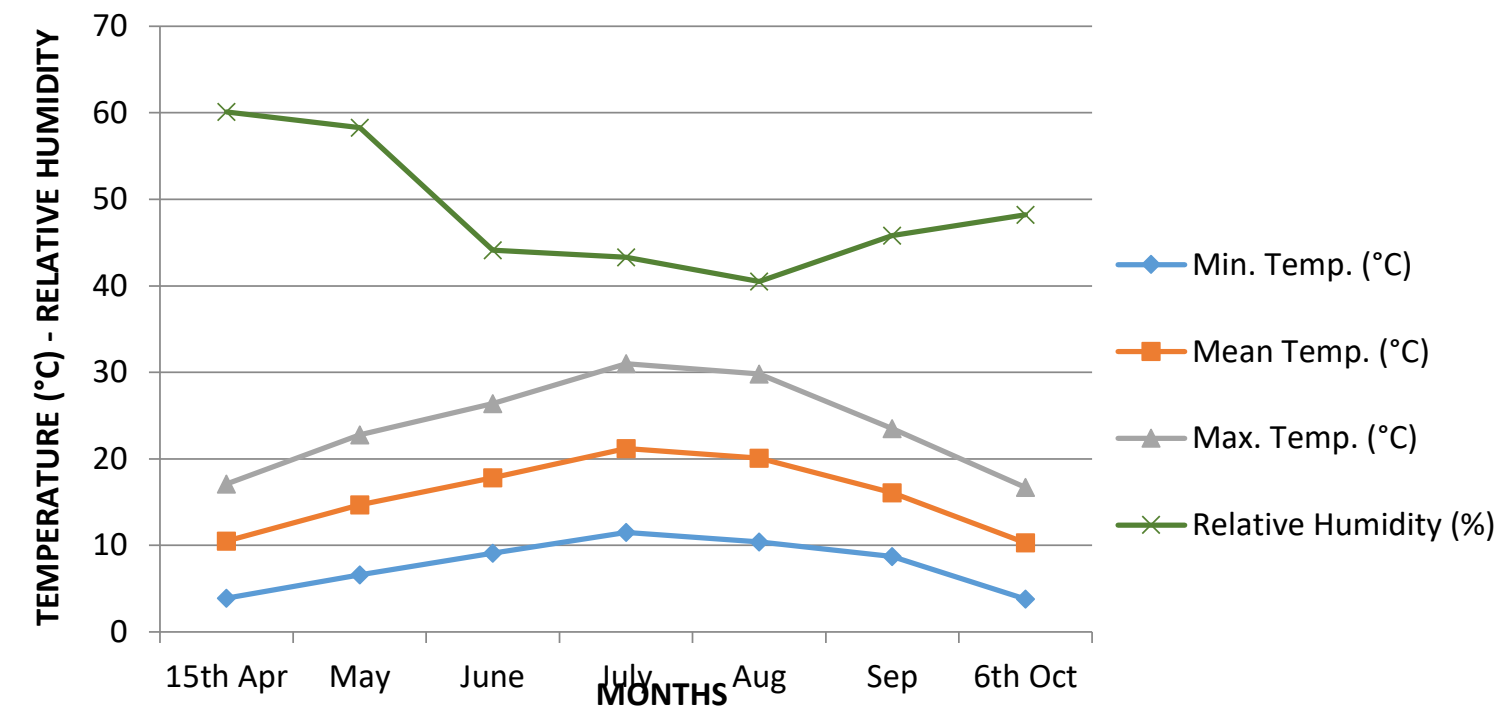

Figure 2. Climatic values between the $15^{\text {th }}$ April $-6^{\text {th }}$ October at the studied site in 2017.

At the result of the study, the highest species richness subgenus was assigned as Liosarcophaga (Table 2). Breeding of S. aegyptica (Povolný and Hula 2004; Pe'rez-Moreno, 2006; Bordas et al., 2007; Abd El-bar and Sawaby, 2011) and S. jacobsoni (Baz et al., 2015) have been tested in small carrions. With respect to some related references and biological notes found in Pape (1987) and Povolný and Verses (1997) for the present species of this subgenus as follows: The larva of $S$. jacobsoni is necrophagous and the adults could be attracted to food market. Adults of
S. emdeni attracted to faeces and food market, but larva is necrophagous and facultative parasitoids of some lepidopteran larvae and bred from some snails. Larva of $S$. portschinskyi is necrophagous and facultative predators of lepidopteran or muscoid larvae, and breeding in snake. Adults $S$. tuberosa visit decomposed materials and larvae are facultative parasitoid of some lepidopteran larvae or other insects and snails and agent of cutaneous myiasis.

The second most diverse subgenus Helicophagella was represented by three species in 
the study. S. melanura is the most reported species from decaying carcass (Pape 1987; Baz et al., 2015; Szpila et al., 2015). Subsequently, S. hirticrus mainly known as snail predators (Pape 1987; Blackith and Blackith, 1990), but some experiments show that it could also be breed in decaying tissues (Castillo, 2001; Pe'rez-Moreno 2006; Prado e Castro et al., 2010). Neverthelesss, there is no available data for the occurrence of $S$. novercoides which is described as parasitoids of some insect and molluscs Blackith and Blackith, 1990).

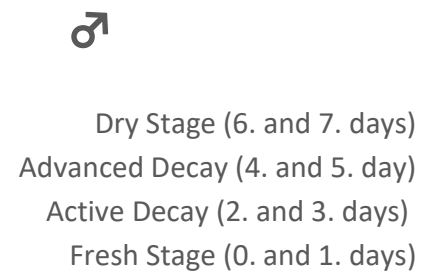

0

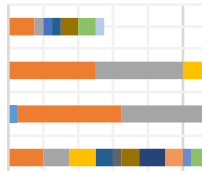
20 120

R. pernix
S. hirticrus
S. argyrostoma
S. jacobsoni
S. bergi

Sarcophila meridionalis

- S. melanura

- S. crassipalpis

S. portschinskyi

- S. lehmanni
S. africa

- S. novercoides

- S. aegyptica

S. tuberosa

T. heteroneura

S. incisilobata

Figure 3. Distributions of the number of the males to the decaying stages.

$$
\text { 우 }
$$

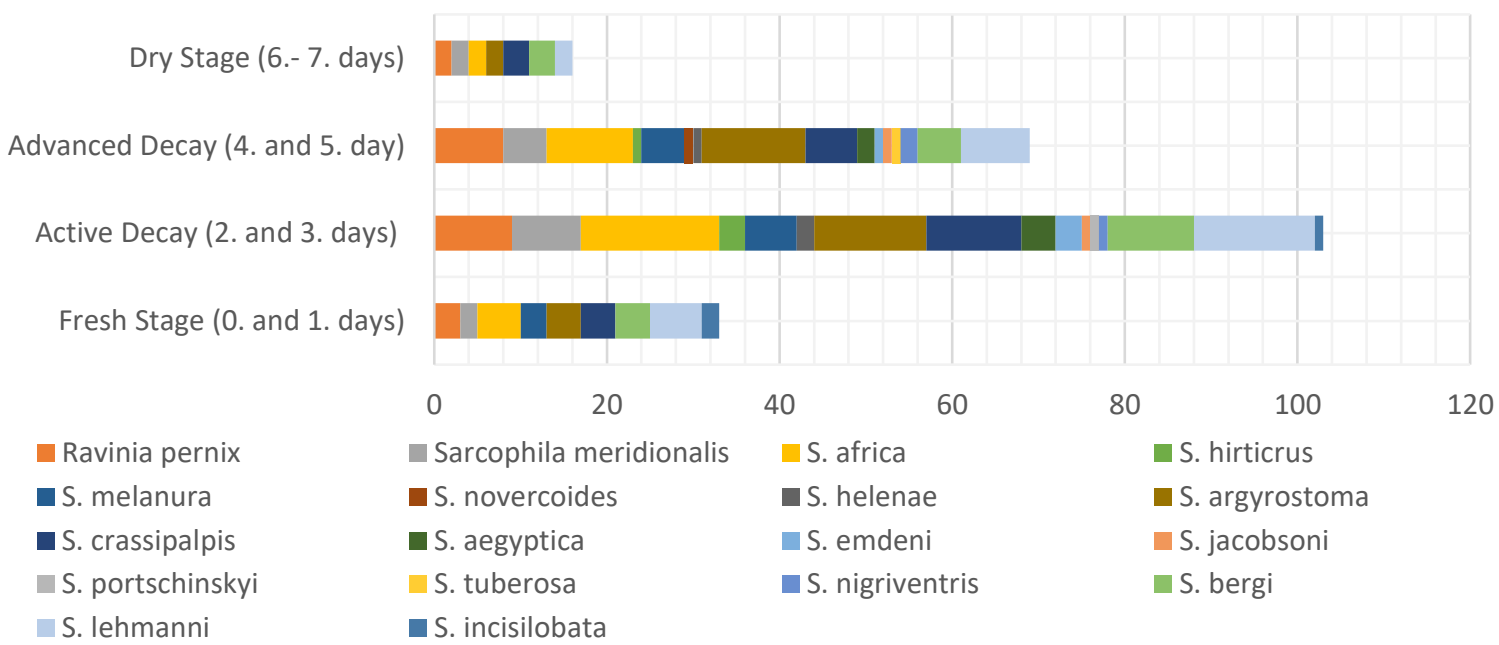

Figure 4. Distributions of the number of the females to the decaying stages.

The most interesting findings of that current study are the identifications of $S$. helenae and $S$. platariae. During the experiments, $S$. helenae was the only species of the subgenus Heteronychia. In Turkey, a total of 15 species are reported and $S$. helenae has a comparatively limited distribution (Verves et al., 2018). Detailed biology is unknown but, in general, known as snail parasitoid (Whitmore, 2010). Different species of Heteronychia have been listed from pig carcass by
Prado e Castro et al. (2010) as Heteronychia (S. (H). vagans, $S$. $(H)$. pandellei and $S$. $(H)$. amita $(=S$. (Discachaeta) amita) and Anton et al. (2011), as $S$. (H.) vicina Macquart 1835.

One of the newly recorded species $S$. platariae (Povolný, 1992) from the subgenus Golania was collected with a total of 18 males. The biology and female is unknown (Povolný 1992).

The results of the many performed studies for the other obtained species are in line with that 
current experiment and consequently reveals that; S. nigriventris (Blackith and Blackith, 1990), S. africa (Pe'rez-Moreno, 2006; Cherix et al., 2012; Szpila et al, 2015), R. pernix, S. argyrostoma, S. incisilobata, S. melanura, S. lehmanni- S. bergi (as S. carnaria group) (Denno and Cothran, 1976; Grassberger and Frank, 2004; Pe'rez-Moreno, 2006; Mulieri et al., 2008; Prado e Castro et al., 2010; Anton et al., 2011; Cherix et al., 2012; Khoobdel et al., 2013; Szpila et al., 2015) and S. crassipalpis (Pe'rez-Moreno, 2006; Mulieri et al., 2008) were also attracted by the different sized of carrions in various habitats. Szpila et al., (2015), also signified the existence of two species of abundant flesh flies (Sarcophila latifrons and $R$. pernix) with the male-biased sex ratios.

In addition to the reasons sorted by some authors (Amendt et al., 2011; Szpila et al., 2015; Rivers and Dahlem 2014), steppe dominant vegetation of Yozgat may be another cause of the unnatural attractions.

\section{Conclusion}

It is clear that, studies based on adult diversity offer limited information to define true necrophagous flesh fly community (Szpila et al, 2015). Furthermore, forensic entomology investigations need much more precise and standardisable results anymore for reliable PMI estimations. Small carrion centred experiments are also quite useful - if only accurate identifications are done- for the monitoring of local variations and the potential necrophagous species determination for further investigations. And even, that may also contribute unexpected new findings as in present the study.

\section{Acknowledgment}

This work is supported by the Scientific Research Project Fund of Yozgat Bozok Üniversitesi under the project number 6602a-ZF/16-42.

\section{References}

Aak, A., Birkemoe, T., Mehl, R. 2010. Blowfly (Diptera: Calliphoridae) damage on stockfish in northern Norway: pest species, damage assessment, and the potential of mass trapping. Journal of Pest Science, 83(3): 329337.

Abd El-bar, M.M., Sawaby, R.F. 2011. A preliminary investigation of insect colonization and succession on remains of rabbits treated with an organophosphate insecticide in ElQalyubiya Governorate of Egypt. Forensic Science International, 208: 26-30.

Açıkgöz, A. 2008. Estimating time of death using the entomological evidences collected on the human corpses. PhD, Ankara Üniversitesi Sağlık Bilimleri Enstitüsü, Disiplinler Arası Adli Tıp Anabilim Dalı, Ankara.

Akduman, D., Arslan, M.O., Gul. 2011. A case of otomyiasis in a child with chronic otitis media. International Journal of Pediatric Otorhinolaryngology Extra, 6(3): 116-118.

Amat, E. 2010. Notes on necrophagous flies (Diptera: Calyptratae) associated to fish carrion in Colombian Amazon. Acta Amazonica, 40(2): 397-400.

Amendt, J., Richards, C.S., Campobasso, C.P., Zehner, R., Hall, M.J.R. 2011. Forensic entomology: applications and limitations. Forensic Science, Medicine, and Pathology.

Anton, E., Niederegger, S., Beutel, R.G. 2011. Beetles and flies collected on pig carrion in an experimental setting in Thuringia and their forensic implications. Medical Veterinary and Entomology, 25(4): 353-364.

Aydenizöz, M., Dik, B. 2008. A case of gingival myiasis in a lamb caused by the Wohlfahrtia magnifica (Diptera: Sarcophagidae). Türkiye Parazitoloji Dergisi, 32 (1):

Baz, A., Botias, C., Martin-Vega, D., Cifrian, B., DiazAranda, L.M. 2015. Preliminary data on carrion insects in urban (indoor and outdoor) and periurban environments in central Spain. Forensic Science International, 248: 41-47.

Beyhan, Y.E., Yılmaz, H., Cengiz, Z., Ayral, A. 2017. $A$ case of aural myiasis caused by Wohlfahrtia magnifica in a child in Turkey. Türk Hijyen ve Deneysel Biyoloji Dergisi, 74(4): 347-350.

Blackith, R.E., Blackith, R.M. 1990. Insect infestations of small corpses, Journal of Natural History, 24(3): 699-709.

Campobasso, CP., Di Vella, G. 2001. Introna F. Factors affecting decomposition and Diptera colonization. Forensic Science International, 120(1-2): 18-27.

Cherix, D., Wyss, C., Pape T. 2012. Occurrences of flesh flies (Diptera: Sarcophagidae) on human cadavers in Switzerland, and their importance as forensic indicators. Forensic Science International, 220: 158-163.

Çoban, E., Beyarslan, 2013. A. Identification of dipteran species of forensic entomology importance in summer season in Edirne. Bitlis Eren University Journal of Science and Technology, 3: 18-21.

Dagci, H., Zeyrek, F., Gerzile, Y.K., Sahin, S.B., Yagcı, S., Uner, A. 2008. A case of myiasis in a patient with psoriasis from Turkey. Parasitology International, 57(2): 239-241. 
Denno, R.F., Cothran, W.R. 1976. Competitive interactions and ecological strategies of Sarcophagid and Calliphorid flies inhabiting rabbit carrion. Annals of the Entomological Society of America, 69: 109-113.

Dik, B., Uslu, U., Işık, N. 2012. Myiasis in Animals and Humanbeings in Turkey. Kafkas Üniversitesi Veteriner Fakültesi Dergisi, 18(1): 37-42.

Ekmekci, P.Ö. 2017. Seasonal distribution and myiasis flies determined in Adıyaman province. MSc, Gaziantep University, Gaziantep, Turkey.

Ergün, S., Akıncı, O., Sirekbasan, S., Kocael, A. 2016. Postoperative wound myiasis caused by Sarcophaga carnaria. Turkish Society for Parasitology, 40: 172-175.

Farkas, R., Hall, M.J.R., Bouzagou, A.K., Lhor, Y., Khallaayou, N.E. 2009. Traumatic myiasis in dogs caused by Wohlfahrtia magnifica and its importance in the epidemiology of wohlfahrtiosis of livestock. Medical and Veterinary Entomology, 23(Suppl. 1): 80-85.

Fremdt, H., Amendt, J. 2014. Species composition of forensically important blow flies (Diptera: Calliphoridae) and flesh flies (Diptera: Sarcophagidae) through space and time. Forensic Science International, 236:1-9.

Grassberger, M., Frank, C. 2004. Initial study of arthropod succession on pig carrion in a Central European urban habitat. Journal of Medical Entomology. 41(3): 511-523.

İpek, D.N.S., Şaki, C.E., Özer. E. 2011. Seasonal distributions of external myiasis flies determined in Diyabakır province. Kafkas Üniversitesi Veteriner Fakültesi Dergisi, 17(3): 469-475.

Irgatoğlu, A.N. 2011. Physical development planning and design of university campuses: Case of Yozgat Bozok University Erdoğan Akdağ Campus. PhD, Ankara University, Ankara, Turkey.

Karapazarlıoğlu, E. 2004. The determination of arthropod's species and succession on pig carcasses in naturel places. MSc, Ondokuzmayıs University, Samsun, Turkey.

Karapazarlığlu, E. 2010. The determination of insect species and their succession on pig carcasses indoors, and a case study. PhD, Ondokuzmayıs University, Samsun, Turkey.

Kaya, F.D., Orkun, Ö., Çakmak, A., İnkaya, A.Ç., Ergüven, S. 2014. Cutanous myiasis caused by Sarcophaga spp. larvae in a diabetic patient. Mikrobiyoloji Bülteni, 48(2): 356361.

Khoobdel, M., Akbarzadeh, K., Jafari, H., Mehrabi Tavana, A., Izadi, M. et al. 2013. Diversity and Abundance of Medically-Important Flies in the Iranian Triple Islands; the Greater Tunb, Lesser Tunb and Abu-Musa. Iranian Journal of Military Medicine, 14(4): 327-336.

Kökdener, M., Zeybekoğlu, Ü., Gündüz, E. 2018. Necrophagous Diptera Diversity in Samsun during Summer Season. Adli Tıp Bülteni, 23(2): 110-114.

Kyerematen, R.A., Boateng, B.A., Haruna, M., Eziah, V.Y. 2013. Decomposition and insect succession pattern of exposed domestic pig (Sus scrofa L.) carrion. ARPN Journal of Agricultural and Biological Science, 8(11): 756-765.

Martin-Vega D., Baz, A. 2013. Sex-biased captures of sarcosaprophagous Diptera in carrionbaited traps. Journal of Insect Science, 13: 14.

Mulieri, P.R., Schnack, J.A., Mariluis, J.C., Torretta, J.P. 2008. Flesh flies species (Diptera: Sarcophagidae) from a grassland and a woodland in a Nature Reserve of Buenos Aires, Argentina. Revista de Biologia Tropical, 56: 1287-1294.

Öktener A., Alas, A. (2009) Cases of External Myiasis Caused by Diptera (Sarcophaga sp.) on three cyprinid species, Reviews in Fisheries Science, 17(1): 68-69.

Özcan, M. 2008. Research and genomic DNA isolation on the populations of the redtailed gray flesh fly Sarcophaga haemorrhoidalis anomalic types and frequency living The Çukurova University Balcalı Campus. MSc, Çukurova University, Adana.

Özdal, N. 2004. The prevalance, development and identification of agent causing traumatic myiasis in cattle, sheep and goat in Van region. PhD, Yüzüncü Yıl University, Van.

Pape, T. 1987. The Sarcophagidae (Diptera) of Fennoscandia and Denmark. Fauna entomologica Scandinavica, 19. E.J. Brill/Scandinavian Science Press Ltd., Leiden, Copenhagen, 203 pp.

Pape, T. 1996. Catalogue of the Sarcophagidae of the world (Insecta: Diptera). Mem Entomology International, 8: 558 pp.

Pe'rez-Moreno, S., Marcos-Garcia, M.A., Rojo, S. 2006. Comparative morphology of early stages of two Mediterranean Sarcophaga Meigen, 1826 (Diptera; Sarcophagidae) and a review of the feeding habits of Palaearctic species. Micron, 37: 169-179.

Polat, E., Sirekbasan, S., Inan, H.C. 2016. Two Cases of Myiasis of Middle Ear Caused by Sarcophaga. Türkiye Parazitoloji Dergisi, 40: 176-178. 
Povolný, D. 1992. Thyrsocnema platariae sp. n., a new species of flesh-fly from Greek Macedonia (Diptera, Sarcophagidae). Acta Entomologica Bohemoslovaca. 89: 383-386.

Povolný, D., Hula, V. 2004. On an invasion of the flesh-fly Liosarcophaga aegyptica (Salem, 1935) into Central Europe with the discovery of Helicophagella verstraeteni (Lehrer, 1975) in East Slovakia (Diptera, Sarcophagidae). Acta Universitatis Agriculturae et Silviculturae Mendelianae Brunensis. 52: 91-101.

Povolný, D., Verves, Y. 1997. The flesh-flies of Central Europe. Spixiana, supplement 24, Munchen, $260 \mathrm{pp}$.

Prado e Castro, C., Garcia, M.D., Arnaldos, M.I., Gonzalez-Mora, D. 2010. Sarcophagidae (Diptera) attracted to piglet carcasses including new records for Portuguese fauna. Graellsia, 66(2): 285-294.

Ren, L., Shang, Y., Chen, W., Meng, F., Cai, J. et al. 2018. A brief review of forensically important flesh flies (Diptera: Sarcophagidae). Forensic Sciences Research, 3(1): 16-26.

Richet, R., Blackith, R.M., Pape, T. 2011. Sarcophaga of France (Diptera: Sarcophagidae). Sofia, Pensoft Publishers. $327 \mathrm{pp}$.

Rivers, D.B., Dahlem, G.A. 2014. The Science of Forensic Entomology. WileyBlackwell, CRC Press, $418 \mathrm{pp}$.

Şaki, C.E., Özer, E. 1999a. Myiasis cases and their treatments in cows, sheep and goats in Elazıg province. Turkish Journal of Veterinary and Animal Science, 23: 261-268.

Şaki, C.E. and Özer, E. 1999b. Morphology and seasonal distributions of external myiasis flies determined in Elazığ province. Turkish Journal of Veterinary and Animal Science, 23: 733-746.

Salona-Bordas, M.I., Moneo-Pellitero, J. and Herrero-Davila, D. 2007. New observations of Liosarcophaga aegyptica (Salem, 1935) (Diptera, Sarcophagidae) reared from colonies collected on the University Campus of Lejona (Vizcaya, Northern Spain). Boletín de la Sociedad Entomología Aragonesa, 40: 377-383.

Şekercioğlu, Ç.H., Anderson, S., Akçay, E. Bilgin, R., Can, Ö.E. 2011. Turkey's globally important biodiversity in crisis. Biological Conservation, 144: 2752-2769.

Sert, O., Kabalak, M., Şabanoğlu, B. 2012. Determination of forensically important Coleoptera and Calliphoridae (Diptera) species on decomposing dog (Canis lupus familiaris L.) carcass at Ankara province. Hacettepe Journal of Biology and Chemistry, 40(1): 99-103.

Sevgili, M., Şaki, C.E., Özkutlu, Z. 2004. External myiasis in the Şanliurfa province: the distribution of flies. Türkiye Parazitoloji Dergisi, 28(3): 150-153.

Szpila, K., Mądra, A., Jarmusz, M., Matuszewski, S. 2015. Flesh flies (Diptera: Sarcophagidae) colonising large carcasses in Central Europe. Parasitology Research, 114: 2341-2348.

Tereli, M., Bayram, A., Tüzün, A. 2015. Determination of species of diptera feeding on carcasses and their evaluation in forensic entomology in Kırıkkale Province. Journal of Applied Biological Sciences, 9 (3): 40-44.

Tschorsnig, H.P., Seris, E., Cobo, A., Cobos, G., Pascual, S. 2011. Tachinidae (Diptera) collected in traps used for mass- trapping of Bactrocera oleae (Rossi) (Diptera: Tephritidae) in olive groves in Central Spain. Spain Journal of Agricultural Research, 9: 1298-1306.

Türk, M., Afşar, İ., Özbel, Y., Şener, A.G., Üner, A., Türker, M. 2006. A case of nasomyiasis whose agent was Sarcophaga sp. Türkiye Parazitoloji Dergisi, 30(4): 330-332.

Ütük, A.E. 2006. Traumatic myiasis in a dog. Fırat Üniversitesi Sağlık Bilimleri Dergisi, 20(1): 97-99.

Vairo, K.P., Caneparo, M.F.C., Corrêa, R.C., Preti, D., Moura, M.O. 2017. Can Sarcophagidae (Diptera) be the most important entomological evidence at a death Scene? Microcerella halli as a Forensic Indicator. Revista Brasileira de Entomologia, 61(4): 275-276.

Verves, Y., Barták, M., Kubík, S. 2018. Checklist of flesh flies of Turkey (Diptera, Sarcophagidae). ZooKeys, 743: 95-136.

Whitmore, D. 2010. Systematics and phylogeny of Sarcophaga (Heteronychia) (Diptera, Sarcophagidae). PhD, University of Rome La Sapienza, Department of Animal and Human Biology, Rome.

Whitmore, D., Buenaventura, E. and Pape, T. 2018. Odd, outsized, and obscure: Sarcophaga (Hadroxena) karakoncolos sp. n. (Diptera: Sarcophagidae) from Turkey. Zootaxa, 4422(3): 385-394.

Yazar, S., Dik B., Yalçın, Ş., Demirtaş, F., Yaman, O., Öztürk, M., Şahin, İ. 2005. Nosocomial oral myiasis by Sarcophaga sp. in Turkey. Yonsei Medical Journal, 46(3), 431-434.

Yuca, P. 2009. Insect fauna of forensic importance from Akfirat locale in Istanbul. MSc, İstanbul University, İstanbul, Turkey. 